TURIZAM

Volume 17 , Issue 3

110-120 (2013)

\title{
Potential for Paragliding Tourism Development in Niška Banja (South Serbia)
}

Lazar Pavić*, Milica Rančić*, Maja Mijatov*

Received: February 2013 | Accepted: August 2013

\begin{abstract}
People today pay attention more on their health and because of that sports tourism becomes more popular. Especially popular segment of sports tourism is adventure sports including paragliding which has a special place. Tourist product of Niška Banja, as one of more visited tourism destination in Serbia, is mostly based on its health function. In the first part of this paper it is presented touristic valorisation of Niška Banja using criteria recommended form World Tourism Organization. In the second part of this paper it is used marketing mix as a tool for creating potential tourism product Paragliding weekend in Niška Banja. The aim of this paper is to show how the tourism offer of Niška Banja can be diversified using a new integrated product and how the touristic value can be increased.
\end{abstract}

Key words: paragliding, tourism, marketing mix, adventure sports, Niška Banja

\section{Introduction}

Sports tourism is defined as "non-commercial travel with the aim of participation in sports activities or watching them, far from place of residence“ (Plavša, 2009). Foszto and Kiss (2OII) define sports tourism as a specific travel outside of usual environment with main reason of active or passive participation in sports competitions while the main motive for travelling is sport, while tourism and leisure are additional elements. According to this, sports tourism can be divided into two categories: travelling with main aim of taking part in sports and travelling with main aim of watching sports. The importance of sports tourism is reflected through a fact that from one of four to one of five tourists is sports tourist. Although there is not accurate information about sports tourism market, some of estimates say that in global it contributes with 30 billion American dollars (Plavša, 2009).

Tourists who travel because of sport (conditionally sports tourists) have some specificities: they must travel to a destination which is minimum $80 \mathrm{~km}$ far and to spend minimum one night to watch, take part in sports activities or some other way included in sports. Sport is the main aim of travelling in that level that tourist choose concrete destination only because of sports activities and they would not choose it unless there are not concrete sports events (Fozto and Kiss, 2OII).

* University of Novi Sad, Faculty of Sciences, Department of geography, tourism and hotel management, Trg Dositeja Obradovića 3, 21000 Novi Sad, Serbia, Corresponding author: lazar_pavic@hotmail.com 
Contemporary tourists tend to active vacation which includes huge number of activities adjusted to individual taste. In the end of 9Os in tourism literature it is appeared a concept of active tourism. It combines three elements: adventure, ecotourism and cultural aspects. In that way are combined recreation, education and benefits for tourist during visiting destination (Iatu et al, 2OIO). Lots of studies tried to describe active tourism, but its principles are not still strongly defined.

\section{Adventure sports and paragliding as a segment of sports tourism}

Which is relation between active tourism and adventure tourism? Active tourism is broader concept from adventure tourism. Adventure tourism includes sports activities with high level of risk and danger, with presence of adrenalin. Kane and Tucker (2004) mark off those two concepts. They consider that active tourism is defined through its main activity, while adventure tourism is closer connected with destination. UNWTO adventure tourism defines as a travel into country or abroad, which includes minimum two of those factors: physical activity, interaction with nature and learning in cultural heritage in function of sharing experience (Spalević, Igračev, 2OII).

Adventure tourism is one of the fastest growing segments of tourism. Since they are located in natural, often ridge locations, those journeys enable tourist interaction with nature through practising lots of activities: climbing, kayaking, gliding, cycling, paragliding etc. Those journeys tend to "searching for excitement", which creates high contrast to everyday routine (Buckley, 2007).

Paragliding is one of the youngest aero sports and it has intensive development. Also, it is one of specific ways of recreation which includes free flying through air using specific mean of transport, paraglider, which is moving using wind. Sport ensued after the Second World War when it helped mountaineers to safe climb down the mountain. The most important preconditions for safe flying are: personal attitude, complete training and safe equipment. A competitive advantage of paragliding as a sports activity is a fact that it does not require special physical activity nor developed tourist infrastructure. The only preconditions are $200 \mathrm{Om}$ high rise and specific wind rose. This sport does not require heavy trainings and big financial invests, so that it is available to everybody. After short theoretical lectures and short training, everyone can engage in paragliding (www.paragliding.org).

Although Serbia has outstanding conditions for development paragliding (70\% of country are mountains), paragliding begins its development in 9os. Reasons for that are not enough representations in media and wrong opinions that it requires huge financial support. Paragliding in Serbia is linked with small number of brave individuals and a few paragliding clubs on a various locations, and the most important are: Vršac tower, Rajac, Sićevo, Kopaonik, Suva planina, Golija. Paragliding clubs train for all interested (Spalević, Igarčev, 2OII).

\section{Tourist valorisation of Niška Banja through paragliding aspect}

Tourist valorisation is a process of fortification or evaluation of tourist attractions, or evaluation of tourist attractiveness of all objects and spaces which have characteristics to be attractive (interesting) for tourists and which can satisfy their tourist needs (Čomić, Pjevač, 1997). Tourist attraction can both be a specific motive on destination or the whole destination. 
World Tourism Organization (UNWTO) gives one of most complex methods for tourist valorisation which can be applied during tourist valorisation of the whole destination through the aspect of one specific tourism form. This method includes internal (X) and external factors $(\mathrm{Y})$ of tourist valorisation. Internal factors include specific characteristics and valued of every tourist resource separately. They are: level of utilization of tourist resources (including three sub-factors: urbanization (A), infrastructure (B) and tourist equipment and services (C)) and inherent characteristic of tourist resource (D). External factors allow using tourist resources on concrete place. They are: accessibility (E), distance from emissive centres $(F)$, specificity of tourist resources $(G)$ and importance of resources $(H)$. All of these factors are evaluated by marks from one to ten (Čomić, Pjevač, 1997).

Urbanization (A). Evaluating of urbanisation includes type, quality and level of current infrastructure. Since Niška Banja is a tourist destination, current tourist infrastructure is on a medium-high level. Non-touristic infrastructure is also good, since Niška Banja is a township which belongs to the city of Nis. Both quality and level of urbanization can be medium rated, but since Niška Banja is a spa place it is not a negative factor. Medium rated urbanisation enables conservation of healing spa properties.

Infrastructure (B). Valuation of infrastructure includes: characteristics of urban and transport infrastructure, level of offered services and level of supply according to market needs. Urban and transport are infrastructure are on the appropriate level. Approach road to Niska Banja is paved. But, if we consider level of offered services and satisfying market needs, we conclude that health services are dominated. Tourist need new, unconventional offer, more intensive experience, more fun and sports, respectively to make offer which will be adjusted to every individual (Ćurčić, 2007). It could make tourist product of Niška Banja more attractive with numerous new forms of tourism, such as excursions, manifestations, transit tourism, congress tourism, hunting tourism and sports tourism.

Tourist equipment and services (C). This factor includes: accommodation capacities, complementary tourist offer and services. Receptive basis of Niška Banja are hotels: Ozren, Partizan, Srbija and wards Radon, Zelengora and Terme. All those objects are categorized with three stars. Beside them, there is a possibility for private accommodation (Romelić, 2008). In the main spa promenade there are a lot of restaurants and the other hospitality objects where guests could use food and drink service. The other tourist services offers Tourist Info centre, also located in the main promenade.

Inherent characteristics of tourist resource (D). The term inherent characteristics of touristic resource include all attractions of resource which are based for its tourist value. Those are all internal characteristics of tourist destination which can build the basis of tourist product (Čomić, Pjevač, I997). Potentials for paragliding tourism in Niška Banja are big. Specific wind rose on a hill Koritnik over Niška Banja, is a great condition for paragliding. Start is on $560 \mathrm{~m}$ and landing on $220 \mathrm{~m}$ altitude. On Koritnik were held state contests in paragliding, which can be additional attraction to sports fans (Romelić, 2008). Paragliding trail Sićevo is the best place for paragliding on Balkan according to climate and orographic conditions. In 2008 in Niška Banja was held European championship in Paragliding (www.explore-serbia. rs). Beside paragliding as a dominant sport, there are also potential some other sports: alpinism, hiking, etc.

Accessibility (E). Accessibility of tourist resource is consequence of relevant transport infrastructure which enables easy coming to it. Niška Banja has good transit position since it is located on E-80 road to Bulgaria and it is 93km far from border crossing Gradina. More, is it is also relevant E-75 road (corridor IO) which connects Subotica and Vranje, over Bel- 
grade and Nis. Airport in Niš is just I4 km far from Niška Banja. Niška Banja is connected with Niš by regular bus lines (Romelić, 2008). Jovičić (2008) asserts that Niška Banja has the best transit position from all of Serbian spas.

Distance from emissive centres $(F)$. This factor could be highly graded since the centre of Nis, the third biggest city in Serbia, is just IO km far. Niš with Leskovac is important emissive area in South Serbia. In gravitational circle there is also important Morava emissive area Jagodina-Ćuprija-Paraćin, while Belgrade and Novi Sad are in the third circle $300 \mathrm{~km}$ far. From neighbouring countries, the best positions have Bulgaria (Sofia) and Macedonia (Skopje).

Specificity of tourist resources (G). Specificity of tourist resources is determined by comparing with resources of similar type and number of these resources. Compared with the other paragliding places, it can be seen that Niška Banja is the only spa in Serbia where tourists can participate in paragliding. The other competitiveness is that Niška Banja had the best conditions in Balkan for paragliding (www.explore-serbia.rs).

Importance of resources $(H)$. Importance of resources estimates with image which product has on market, respectively with volume of demand and possibilities of commercialization. Image of Niška Banja is like that it is a sanatorium destination. By including new products and appropriate marketing activities, it can be done changes in tourist minds (Ćurčić, 2007). In accordance with the Strategy for Tourism Development in Republic of Serbia, active relaxation could be realised through product Special interests, where paragliding is one of possible activities (Strategy for Tourism Development in Republic of Serbia, Ministry for trade, tourism and services, 2005).

Table 1. Tourist valorisation of Niška Banja through paragliding aspect using UNWTO criteria

\begin{tabular}{|l|c|c|}
\hline FACTORS & MARKS (1-10) & TOTAL( $\Sigma$ ) \\
\hline Internal factors (X) & & $35 / 40$ \\
\hline Urbanisation (A) & $8 / 10$ & \\
\hline Infrastructure (B) & $7 / 10$ & \\
\hline Touristic equipment and services (C) & $10 / 10$ & \\
\hline Inherent characteristics (D) & $10 / 10$ & $37 / 40$ \\
\hline External factors (Y) & & \\
\hline Accessibility (E) & $10 / 10$ & \\
\hline Distance from emissive centres (F) & $10 / 10$ & \\
\hline Specificity of resources (G) & $10 / 10$ & $72 / 80$ \\
\hline Importance of resources (H) & $7 / 10$ & \\
\hline TOTAL ALL & & \\
\hline
\end{tabular}

With total mark 72/80 it can be concluded that Niška Banja has very high tourist value for paragliding tourism development (Table I). With appropriate marketing activities, it can increase tourist traffic and consumption. Jovičić (2008) asserts that Niška Banja, with about IOO.OOO overnight stays per year is in a group of Serbian spas with pronounced seasonality. Those parameters could highly increase if Niška Banja would introduce new tourist products. 


\section{Marketing mix as a tool for creating a tourist product}

Marketing concept is doing business activities which direct products and services from producer to consumer or user. The main characteristic of marketing concept is market focusing. The marketing process begins from informing the market and it finishes with satisfying customer needs. The main focus of every marketing concept is consumer. Tourist subject can affect on in using factors that it controls, and all of those factors used in some combination are known as marketing mix. The instruments of marketing mix are: product, price, place and promotion. This is famous Mc Carthy's 4P model (Ćurčić, 2007).

The biggest problem of marketing plans is that they can be too long. In this paper is used Kelly Odell's marketing plan matrix (www.thinktank.se). This is the shortest marketing plan on the world consists of matrix which combines Mc Carthy's 4P model with 6 questions (what, why, when, how, how much and who) which gives 24 fields in total.

Element product gives answers to these questions: what products do you need, what need does it fill, when do you need it, how will product fill the need, product cost, volume to be sold and customer segments to be target. Element price gives answers to these questions: what price will you sell for, why is that the right price, how long will that price be valid, how will the price develop overtime, how much sales and margin will be created and different prices for different segments. Element place gives answers to these questions: how will products be distributed, why choose these channels, when do customers choose different channels, how will be create or enter these channels, what are the cost/benefits of these channels, how do different segments use different channels. The last element, promotion, answers to this: what types of promotion will be used, why chooses these activities, timing question, how will the promotions be executed, costs/benefits of the promotions, target groups for various promotions (www.thinktank.se).

When we talk about tourism market, product is an unique concept which includes both products and services into tourism offer. Bakic (I988) asserts that tourist product is a partial element of producer on the customer side or functional concept of more elements (integrated) which final look gives customer by choosing and mixing those elements. No one marketing element cannot be treated separately, because the best effect gives its combination and interaction on the market. However, there is an opinion that before making decision about marketing mix strategy, particularly long-term decisions, the most important element is product, whom the rest elements give support (Jovičić, 20O2).

Partial tourist product is product from one producer on tourist market which he offers individually. This product only partially satisfies customer needs. Integral tourist product is making product on a destination level, which framework is offer consists of all economic and noneconomic activities which satisfy tourist needs. Total satisfying of tourists needs achieves by using integral tourist product and this reflects on its importance. According to that, touristic product Paragliding weekend in Niska Banja will be presented as an integral product, travel arangement, consisted of more separate services.

\section{Marketing mix for potential tourism product: Paragliding weekend in Niška Banja}

Product presentation. Tourism product "Paragliding weekend in Niška Banja" is a complex product made up of a number of coordinated services, and main of them is opportunity for practicing paragliding. Transportation, accommodation and food are base of this prod- 
uct, just like of any other tourism product. As previously indicated, Niška Banja has a very favorable geographical position. It is very easy to get to Niška Banja by modern highway, and comparative advantage of Niška Banja is proximity of airport Constantine the Great in Niš (about I4 km). For foreign guests who will arrive in Serbia by airplane, we will provide a transfer service to the hotel. Accommodation and food will be organized into two hotels (Partizan and Ozren) and they will include half-board (breakfast and dinner). The initial service would be check-in (Friday night) and dinner. Breakfast service (Saturday morning) will follow the first night in Niška Banja. Then will be organized a gathering of all participants of this arrangement, and they should be notified about gathering one night before. Gathering should be organized in one of the halls with suitable capacity, depending on the number of participants of arrangement. For that occasion, eminent instructors are going to teach participants about paragliding by one hour theoretical lecture. After that, participants of arrangement will be transported to the airfield Sićevo. After arrival at the airfield, instructors will continue to teach participants about paragliding, now in practical terms. The practical training will include the following sections: introduction to paragliding equipment and instructions for their use, presentation of the flight and advices about behavior during the flight and the flight demonstration. For those who are not experienced in this sport, there is the possibility of using a tandem paraglide, together with instructor. After landing, lunch will be served on the grass, where participants will be served with traditional specialties of the local cuisine from this region. After lunch, each participant had to choose one of the additional activities in the afternoon: hiking, horseback riding, walking in nature or an optional trip to Niš (sightseeing with a local guide and free time). Participants need to make a declaration about preferred optional activity earlier, because it is necessary to provide adequate services in time. Time after returning to the hotel is predicted for dinner and overnight. The next day (Sunday), time after breakfast is planned for another trip to the airfield Sićevo. Morning is again reserved for paragliding, while in the afternoon participants can use wellness properties of Niška Banja, for relaxing after active sport. The wellness center includes all attractive and modern wellness programs: a sauna, vibrating sauna, Jacuzzi, massage, essential oils, etc. This will be the last service of the arrangement, followed by leaving of participants from the hotel, except for foreign guests, because for them is going to be organized transfer to the airport.

Selection of target market segments in relation to the characteristics of the tourism product. This product can satisfy a lot of tourist's needs: the need for change, rest and recreation, socializing, playing and more. It can also provide an opportunity to experience pleasant moments of tension and excitement, which is a significant contrast of everyday life in modern society. Paragliding is a specific type of adventure sport, and therefore it requires specific microclimate. The right strength of wind and clear weather with no precipitation are necessary conditions in order to be able to run flights. This means that, except winter, the rest of the year is suitable for practicing paragliding, especially in spring and autumn. As paragliding is extreme sport with specific characteristics, people who are involved in this sport are also distinguished, and that fact should be considered during the selection of target market segments. By consideration of criteria for market segmentation, and performances of this product, we can extract the following target segments: (I) tourists from neighbouring countries, because of the most suitable climatic conditions for paragliding at Balkan; 2) young tourists, because they are more prone to adventure sports; (3) business people, because they are working during the week and over the weekend they need a change and mental rest;(4) athletes, because they are normally active and usually like to try different sports. Due to the quality and specificity of this 
product, it is assumed that the demand for it will be high, but in order to achieve this, it is necessary to make a good plan of promotional activities.

Price. Price is one of the key instruments of marketing policy and important marketing mix element to which consumers are very sensitive. Therefore, it is necessary to pay special attention at price forming, because the amount of the price depends on the purchasing power of tourism demand (top border of price), and then on other factors: costs, price competition, free time, developed habits of travelling (low border of price) (Ćurčić, 2007). In our example, the price of the tourism product "Paragliding weekend in Niška Banja" is a set of prices for different services: accommodation on half-board base, services related to paragliding, lunch on the grass, extra activities and wellness services. Here are listed parts of this tourism product, while we could not speak about individual prices with certainty precisely because prices depend on many factors. Compared with its competitors, it can be concluded that the price of the product shall be higher, because it is a specific tourism product, unique in Serbia, with specific target group. Price differentiation has important influence on price forming, with regard to the existence of different prices for the same product in relation to the same or different customers. There are a lot of criteria for the differentiation of prices, while for this product could be taken only some of them: (I) Time of buying product: tourists who sign up earlier will get a certain percentage of discount, depending on the time of application. Discount will be higher for earlier application; (2) Quantity or scope of services: one of the tourists will not pay anything (this applies for applications for four tourists). Tourists who want to come for the third time in Niška Banja to use our product will get one part of this product for free (free wellness service, for example); (3) Market segments: we can provide discounts for certain sport clubs and associations, discount for employees in some companies on the basis of signed contract about long-term cooperation. Prices of this product will not be constant, they will vary. In the initial stage, the stage of product introduction, the price will be lower by $20 \%$ compared to the later period, when the product is going to be recognized and affirmed in the tourism market.

Distribution. Distribution is about how a business gets its products to the customers. The purpose of distribution is the realization of approaching to selected market segments. There are direct and indirect distribution channels. It is most objective to use a type of selective distribution, through carefully selected points of sale for " Paragliding weekend in Niška Banja", because it is the best way for informing selected market segments, and efficient way for communicating with those segments. From direct distribution channels, certainly the most important is the Internet. Therefore, it is necessary to allow reservations directly through the website or by sending an e-mail. In this way, it is easy to come closer to each market segment. Using the Internet for marketing in tourism is of paramount importance. Promotion and general communication with potential tourists were much more difficult before the Internet. Also, the Internet facilitated researching of market (Rančić et al., 2OI2). Sale of this product should be focused to the indirect distribution channels because this type of distribution has a dominating share in the international market. In line with our commitment to selective form of distribution, "Paragliding weekend in Niška Banja" will be put up for sale at reputable travel agents in the country and abroad. Also, the plan is the inclusion of this product in offer of travel agencies - specialists who sell arrangement related to adventure sports and special interests.

Promotion. Promotion consists of various forms of communication with potential customers, in order to create a positive image about the tourism product, customer's orientation to specific offer and initiating purchases by these customers. In order to achieve this, it 
is necessary to make a good and proportionate combination of promotion instruments, primarily defining its goals. Aims of promotion are: strengthening of awareness of the need for the paragliding and launching of that need into the action, informing potential tourists about the existence of product "Paragliding weekend in Niška Banja" approximation of this product to tourists, emphasis of specific features and advantages relative to competitors. Promotion mix consists of the following elements:

\section{1) Tourism propaganda}

Prospects, leaflets and brochures. All target segments can be reached by prospects, leaflets and brochures, primarily because they are classified like most widespread and most popular form of advertising and sale strategy. Prospects and brochures have high quality photographs, which results in attracting of attention and creating an image about this product (Ćurčić, 2007). Also, it is important to print prospects, leaflets and brochures in English for foreign tourists.

Advertisements in newspapers and on television. Potential tourists can realize specific features of this tourism product through text, images, or through combination of these two elements. (Ćurčić, 2007). Advertising of paragliding weekend should be presented in daily newspapers and specialist sports magazines. Advertisements in daily mail are suitable for business people, and advertisements in sport magazines are suitable for athletes. Television advertisements will be aired on television stations with national frequency. Also, through cable television it will be available to potential tourists in neighboring countries.

Presentation at tourism fairs. It should take place in the stand of Tourism Organization of Niš (local fairs) or the Tourism Organization of Serbia (international fairs). This is a good way of promotion, and there are many benefits of trade fairs, and most important of them are: the realization of large number of contacts with customers, the possibility of detailed presentations, the ability to launch promotional resources and a high turnover of people.

Websites. The Internet is now the most important medium for advertising, mostly because of its interactivity, accessibility, distribution and visualization (Stankov, 2OIO). It is necessary to create web presentation for this product, but also it is important to promote the product through websites of Tourism Organization of Niš and Niška Banja. On the site, product would be presented in details with all services that are included, and there should be the possibility of online registration. This instrument of promotion is good for all market segments, particularly the foreign tourists. They can be available through the Internet, so the existence of the English language at site is necessary. Banners on the website of Tourism Organization of Serbia can be very practical. In line with the growing popularity of social networks, creating of official Facebook page is going to be awaited marketing move.

\section{2) Personal selling}

This is the most effective form of promotion, because it is the personal interaction between people. Advantages of personal selling are adapting to customers, helping customers in purchasing, advising and giving suggestions (Ćurčić, 2007). Tourism fairs are the best place for achieving personal sales. 


\section{3) Sales advancement}

This means introducing the fun and excitement in promotion, with participating of tourists themselves in the promotion (Hadžić, 2005). It may also encourage the purchase by tourists who have never been tried out in paragliding. For example, if you make application for a group of four people, you will get the fifth place free, then a certain discount for earlier applications, depending on date of application. Also, there is the possibility of including promotional contests through television shows, and the best participants of these contents can get a free " Paragliding weekend in Niška Banja" for two people.

\section{4) Public Relations}

The aim of this promotional technique is to create a positive image about the product. The most important place in public relations is taken by media relations, but we must mention the relations with customers and with employees (corporate image) (Ćurčić, 2OI2). When it comes to a specific product, good relations can be maintained at ceremonies and events.

\section{5) Direct Marketing}

This is an interactive form of marketing in which a direct two-way communication takes place, using the media, such as e-mail, telephone, Internet. Some of advantages are: personalization, privacy of measurability of results (Hadžić, 2005). The plan is to send the envelope with the offer of products and attachments to selected recipients at home addresses. Except prospects, in the envelope can also be a coupon for discount. Also, it is good to send brochures in electronic form to e-mail addresses. Since the product is new on the market, and there are still no loyal consumers, then criteria for the selection of potential tourists are going to be selected market segments.

\section{Conclusion}

Adventure sports are becoming more popular as tourist brand, because they can help people to escape from the routine of everyday life. These trips can also help them to deal with unusual activities in pristine nature. The development of this type of tourism depends on the initiative of local authorities, entrepreneurs and enthusiasts. Also, adventure sports are a good supplement to other forms of tourism, such as spa and rural tourism, and that is confirmed by our example.

Through the introduction of a completely new product on market, we diversify the existing tourism of Niška Banja. The marketing mix is a condition for the achievement of better results in the tourism business. Therefore, it is necessary to define and implement appropriate marketing concept, which should ensure the coordination of all participants on a specific tourist market. Also, making of appropriate decisions and implementation of specific tasks are important. This is the reason why modern tourism tends to individual, spontaneous and creative holiday experience, which involves changes, and the reason why creation of new tourism products must be significantly different from the usual supply.

During the formation of paragliding weekend in Niška Banja, the role of marketing is to answer properly on the demand and supply in the market and, based on these parameters, to adjust the product to demands of tourists. Some of these marketing activities should be car- 
ried out at the level of tourism destination, and some of them at the level of the country as a whole. Because of that, it is necessary that all stakeholders in the business of tourism policy accept the role of marketing orientation as an organizational basis. The formation of this product involves active cooperation and coordination of all stakeholders. Their goal has to be channeled through a coordinated policy of all stakeholders, because it is important to set this tourism product like integrated, not in partial form, because of synergistic effect. In addition of this, forming of this integrated tourism product must consider the needs and desires of tourists who will come to Niška Banja because of the paragliding weekend.

Niška Banja can achieve many benefits through diversification of this product. Paragliding weekend could bring a large number of fans of this sport to Niška Banja. Fans of this sport are often ready to travel long distances if particular place provides adequate conditions for practicing paragliding, and Niška Banja certainly can offer that. This would bring more tourists in Niška Banja, and it is a fact that paragliding weekend would allow to overcome the arrival of guests at this spa exclusively for health reasons.

Finally, it will be presented some of the limitations of this study. First, it can be noted that a small number of people in Serbia are engaged in paragliding. The reasons of this are high decentralization of tourism, the absence of legislation, the ailing tourism infrastructure, lack of knowledge in the field of marketing and promotions. These limitations can be removed through using of presented marketing mix. Another disadvantage can be a negative effect on the environment caused by this sport. All paragliding tourists must be aware of the negative impact on the environment caused by this sport, therefore, development must be controlled and consistent through the principles of sustainable development. Finally, we should point to a psychological barrier, especially fear of practicing paragliding, as one of the negative aspects of this product. Through proper propaganda messages, it must be created confidence among tourists in the professionalism of staff who will train them. Also, it is necessary to provide adequate and professional training for tourists who choose to be involved for the first time in paragliding. After returning from a paragliding weekend, tourists who overcome their fear will talk about that with their friends, which is also good type of promotion.

This project is now just an interesting idea, the idea about potential tourism product. This idea, however, is based on the real nature and material resources, which do exist, so it is only necessary to edit and integrate them well, and then offer this product to the right market segments. In the end, it is important to implement quality promotion, which can be based on the exposed marketing mix.

\section{References}

Bakić, O., (I988). Strategijsko planiranje turističkog proizvoda (Strategic planning of tourism product). Naučna knjiga, Beograd.

Buckley, R. (2007). Adventure tourism products: price, duration, size, skill, remoteness. Tourism Management, 28, I428-I433.

Čomić Đ., Pjevač, N., (1997). Turistička geografija (Tourism geography), Federativni centar za promociju ugostiteljstva, Beograd.

Ćurčić, N., (2007). Kvalitativna ocena sredstava turisticke propagande i primenjenog kartografskog materijala u funkciji unapredjenja promotivnih aktivnosti u turizmu (Qualitative evaluation of resources and tourist propaganda cartographic material applied in 
order to improve the tourism promotion activities), Ph.D. Thesis, Prirodno-matematički fakultet, Novi Sad.

Ćurčić, N., (2OI2). Marketing orijentacija u funkciji generisanja turističkog proizvoda (Marketing orientation as a function of generating tourism product), Sedmi naučni skup sa međunarodnim učešćem, Turizam: Izazovi i mogućnosti, tematski zbornik radova, 523530.

Fozsto, M., Kiss A.I. (2OII). Future perspectives of sport tourism in Covasna country, Lucrari stiintifice, seria I, vol. XIII (4).

Hadžić, O., (2005). Kulturni turizam (Cultural Tourism), Prirodno-matematički fakultet, Novi Sad.

Iatu C., Boghincuic M., Coca A., Ibanescu B., Munteanu A., (2OIO). Preliminary Study of Active Tourism Stages in Dornelor Basin, Romania, Proceedings of the 5th WSEAS International Conference on Economy and Management Transformation, Volume I, II3II9.

Jovičić, D., (20O2). Menadžment turističke destinacije (Management of tourism destination), Preduzece za zeleznicku izdavacko-novinsku delatnost d.o.o, Beograd

Jovičić, D., (2008). Stanje i perspective razvoja banjskog turizma u Srbiji (State and perspectivities of spa tourism in Serbia), Glasnik srpskog geografskog društva, LXXXVIII, 3-I8.

Kane, M. J., Tucker, H., (2004). Adventure tourism, the freedom to play with reality, Tourist Studies, Sage Publications.

Plavša, J., (2009). Sportsko-rekreativni turizam (Sport and recreational tourism), Faculty of Science, Novi Sad.

Rančić, M., Pavić, L., Mijatov, M., (2OI2). Internet marketing na primeru onlajn turističke agencije - studija slučaja Putnik travel (Internet marketing on the example of on-line travel agency-Putnik travel case study), Sedmi naučni skup sa međunarodnim učešćem, Turizam: Izazovi i mogućnosti, tematski zbornik radova, 447-457.

Romelić, J., (2008). Turističke regije Srbije (Tourism regions of Serbia), Prirodno-matematički fakultet, Novi Sad.

Spalević ., Igarčev N., (2OII). The natural-geographical basics for the development of the adventure tourism in Serbia, Journal of the Geographic Institute „Jovan Cvijic" SASA 6I(3), I37-I5O.

Stankov, U., (2OIO). Veb marketing i geografski informacioni sistemi u turizmu Vojvodine (Web marketing and GIS in tourism of Vojvodina), PhD Thesis, Prirodno-matematički fakultet, Novi Sad.

Tourism strategy of Republic of Serbia, Ministry for trade, tourism and services, 2005.

www.explore-serbia.rs

www.paragliding.org

www.thinktank.se 